\title{
DELIK EUTHANASIA YANG DILAKUKAN MELALUI BANTUAN TENAGA KESEHATAN DITINJAU DARI PERSPEKTIF FILSAFAT PANCASILA
}

\author{
Gunawan Napitupulu, Musa Darwin Pane \\ Fakultas Hukum Universitas Komputer Indonesia \\ kemalnapitupulu@gmail.com,musa@email.unikom.ac.id
}

\begin{abstract}
Euthanasia is the Act of termination of life quietly and done by the help of others, not all countries regard the right to die as the rights so that the ban took place in various countries including indonesia. Through the regulation in article 344 of the PENAL CODE eliminates the life of another with a seriousness that person is banned, while the Pancasila was seen giving space for implementation of Euthanasia. Pancasila Indonesia because the country provide a space using the Pancasila as the nation's fundamental and Pancasila has one soul namely the divinity of the one true God with the existence of God into the meejawantahkan sense of Justice, namely Judges as Vice Lord upfront. Based on the theory of the law of nature or natures (neutral law theory) that people obey the law because God or nature desires so, this theory held up to the middle ages and foams are distinguished between natural law theory sourced kan agaman that returns everything on God's will. the authors looked at with reviews of the existence of Euthanasia as a new law. A country practice implemented by the Republic of Indonesia has banned an action that is referred to as the Act of suicide, but one side of the death penalty is still used to this day. The spirit of the nation of Indonesia, became an idea that this nation will be more advanced. Euthanasia as a step backwards for some people, but also as intelligent step looked at his role as future laws into social control that the law will always move follow the dynamics of the community.
\end{abstract}

Keyword: Euthanasia, Suicide, Pancasila

\begin{abstract}
Abstrak
Euthanasia adalah tindakan pengakhiran hidup secara tenang serta dilakukan oleh bantuan orang lain, tidak semua negara memandang hak mati sebagai hak sehingga larangan terjadi di berbagai negara termasuk indonesia. Melalui peraturan dalam Pasal 344 KUHP menghilangkan nyawa orang lain dengan kesungguhan orang tersebut merupakan perbuatan yang dilarang, sementara Pancasila dipandang memberikan ruang untuk Implementasi Euthanasia. Pancasila memberikan ruang sebab negara Indonesia menggunakan Pancasila sebagai fundamental bangsa dan Pancasila memiliki salah satu jiwa yakni Ketuhanan Yang Maha Esa dengan artian meejawantahkan keberadaan Tuhan kedalam peradilan yaitu Hakim sebagai wakil Tuhan dimuka bumi. Berdasarkan teori hukum alam atau kodrat (neutral law theory) bahwa orang menaati hukum karena tuhan atau alam menghendaki demikian, teori ini dianut hingga abad pertengahan dan busa dibedakan antara teori hukum alam yang bersumber kan agaman yang mengembalikan segala sesuatunya pada kehendak tuhan.penulis memandang dengan tinjauan keberadaan Euthanasia sebagai hukum baru. Praktik bernegara yang dilaksanakan oleh negara republik Indonesia telah melarang tindakan yang disebut sebagai tindakan bunuh diri, namun satu sisi hukuman mati mas ih digunakan sampai pada hari ini. Semangat bangsa Indonesia, menjadi gambaran bahwa bangsa ini akan semakin maju. Euthanasia sebagai langkah mundur bagi sebagian orang, namun juga sebagai langkah cerdas memandang hukum kedepan sebagai peran nya menjadi social control bahwa hukum akan selalu bergerak mengikuti dinamika masyarakat.
\end{abstract}

Kata kunci: Euthanasia, Bunuh diri, Pancasila 


\section{PENDAHULUAN}

Indonesia merupakan salah satu negara yang memeiliki sejarah jatuh-bangunnya bangsa-bangsa dan peradapan memberi pelajaran bahwa perkembangan suatu bangsa sangat ditentukan oleh karakter, etos, dan etika sosial. ${ }^{1}$ Negara meletakan hak dasar kemanusiaan dalam konteks keIndonesiaan, dalam praktiknya negara republik Indonesia melarang tindakan yang disebut sebagai tindakan bunuh diri yang dibantu oleh orang lain atau disebut juga sebagai tindakan euthanasia.

Euthanasia merupakan tindakan pengakhiran hidup secara tenang serta dilakukan oleh bantuan orang lain dalam hal ini tenaga kesehatan. Dalam perkembangan keilmuan kedokteran sendiri mempelajari dari Euthanasia yang terdiri dari dua jenis, yaitu Euthanasia pasif dan Euthanasia aktif. Kedua ini sangat berbeda dalam pengaplikasian nya. Pada sisi yang berbeda hukuman mati masih digunakan sampai pada hari ini. Dinamika dunia IPTEK bukan sekedar fase transisi dan ternayata mengakibatkan keadaan yang menimbulkan perkembangan dan akhir nya menyambangi dunia kedokteran dan medis. Perubahan yang cukup pesatnya hal baru menjadi tantangan besar untuk mengontrol dan menghadirkan perubahan yang lebih efisien serta tidak bertentangan dengan hakikat suatu bangsa. Kondisi diatas apakah masih memungkinkan bahwa euthanasia itu dilarang, karena pandangan penulis Pancasila sebagai fundamental negara republik Indonesia ternyata memberikan ruang untuk dijadikan sebagai hak yang diberikan kepada setiap orang sebagai fasilitas yang harus didapatkan oleh masyarakat.

Dunia kedokteran yang telah banyak mengalami perubahan dalam fasilitasnya dapat membantu dengan ketepatan akurasi dalam mendiagnosa keluhan yang diperlukan oleh masyarakat. tindakan medis dilakukan kepada seseorang orang untuk hanya mengobati bahkan hinga mengetahui umur dari salah satu pasien, dengan melihat kegagalan-kegagalan fungsi dari organ manusia tersebut. Dahulu dunia kedokteran dan kesehatan masih didasari dengan kemampuan dari individu tenaga kesehatan, seiring percepatan masa teknologi tenaga kesehatan dapat ber Improvisasi ilmu pengetahuan serta kompetensi nya dengan kolaborasi teknologi dibidang kesehatan. Berbagai negara terutama negara-negara maju pada saat ini sudah dapat melakukan riset hingga mampu melakukan birth technology dan biological engineering. Tujuan nya tidak lain membantu tenaga kesehatan untuk mendiagnosis penyakit yang ada didalam tubuh seseorang serta mampu melihat persentase tingkat keberhasilan untuk melakukan pengobatan dan peluang kematian nya. Fase-fase pertumbuhan dan perkembangan manusia dari pembuahan hingga hadir dan hidup secara garis besar dapat berjalan konsisten secara alami. Keadaan berbeda dengan kematian yang juga pasti akan dialami oleh setiap orang dibelahan bumi ini. Pembahasan soal kematian memang menjadi persoalan dan perdebatan di belahan bumi ini. Karena akhir dari rangkaian proses pertumbuhan dari awal hingga berakhir dengan kematia merupakan kehendak Tuhan. Kondisi berbeda akan dialami oleh seseorang yang memiliki penyakit dengan diagnosa yang cukup parah untuk ditangani atau disembuhkan. Aset pribadi yang dimiliki dalam hal ini tubuh dari pasien harus lah menjadi hak pasien untuk menentukan pilihan yang tepat untuk diri nya tanpa terkecuali kematian yang akan dia pilih. Hak hidup merupakan hak yang melekat pada setiap insan manusia, begitu juga harus nya terhadap kematian atau pengakhiran kehidupan dijadikan dan diberikan hak kepada individu-individu.

Kondisi individual rakyat indonesia dihadapkan pada kondisi fisik yang tidak sehat atau maksimal fungsi organ tubuh dari individu. Seperti yang dikatakan Gandhi

\footnotetext{
${ }^{1}$ Yudi latif, Negara Paripurna, Gramedia pustaka utama, Jakarta, 2011, hlm 5.
} 
yaitu, saya seorang nasionalis, tetapi kebangsaan saya adalah perikemanusiaan, ' $M y$ nationalism is humanity' Euthanasia merupakan tindakan pengakhiran hidup secara tenang serta dilakukan oleh bantuan orang lian dalam hal ini tenaga kesehatan. Dalam perkembangan keilmuan kedokteran sendiri mempelajari dari Euthanasia yang terdiri dari dua jeni, yaitu Euthanasia pasif dan Euthanasia aktif. Kedua ini sangat berbeda dalam pengaplikasian nya. Pada praktek nya Euthanasia ini sering terjadi pada pasien dirumah sakit, namun hal tersebut tidak termasuk kedalam kategori aktif. Keadaankeadaan demikian membuat banyak orang serta tenaga kesehatan menjadi dilema, sementara konsekuensi yang akan diterima tidaklah mudah.

Indonesia memang belum mengatur secara spesifik mengenai Euthanasia. Euthanasia atau menghilangkan nyawa orang atas permintaan dirinya sendiri sama dengan perbuatan pidana menghilangkan nyawa seseorang. Dan hal ini masih menjadi perdebatan pada beberapa kalangan yang menyetujui tentang Euthanasia dan pihak yang tidak setuju tentang Euthanasia. Pihak yang menyetujui Euthanasia dapat dilakukan, hal ini berdasarkan bahwa setiap manusia memiliki hak untuk hidup dan hak untuk mengakhiri hidupnya dengan segera dan hal ini dilakukan dengan alasan yang cukup mendukung yaitu alasan kemanusian. Dengan keadaan dirinya yang tidak lagi memungkinkan untuk sembuh atau bahkan hidup, maka ia dapat melakukan permohonan untuk segera diakhiri hidupnya.

Sementara sebagian pihak yang tidak menyetujui tindakan Euthanasia beralasan bahwa setiap manusia tidak memiliki hak untuk mengakhiri hidupnya, karena masalah hidup dan mati adalah kekuasaan mutlak Tuhan yang tidak bisa di ganggu gugat oleh manusia. Perdebatan ini tidak akan pernah berakhir, karena sudut pandang yang dipakai sangatlah bertolak belakang, dan lagi-lagi alasan perdebatan tersebut adalah masalah legalitas dari perbuatan Euthanasia. Walaupun pada dasarnya tindakan Euthanasia termasuk dalam perbuatan tindak pidana yang diatur dalam pasal 344 Kitab Undangundang Hukum Pidana (KUHP).

Berdasarkan pemaparan diatas, melatar belakangi penulis untuk mengangkat judul "Delik Euthanasia Yang Dilakukan Melalui Bantuan Tenaga Kesehatan Ditinjau Dari Perspektif Filsafat Pancasila" dengan rumusan masalah, yaitu Bagaimana Penegakan Hak Hidup dan Hak Mati seseorang di Indonesia ditinjau dari Filsafat Pancasila ? dan Bagaimana Penerapan delik Euthanasia sebagaimana ketentuan dalam Pasal 344 KUHP menurut sistem Hukum Indonesia ?

\section{Me tode Penelitian}

Metode penelitian dalam penulisan ini Bersifat deskriptif analisis yakni dengan menitikberatkan perhatian terhadap masalah yang dibahas dan menjelaskan mengenai beberapa data berupa peraturan perundang-undangan yang berlaku sesuai dengan permasalahan tersebut, serta menelaah teori-teori hukum meliputi pendapat dan doktrin para ahli, kemudian dikaitkan dengan praktik pelaksanaanya. Sedangkan Metode Pendekatan yang dilakukan oleh penulis dalam penelitian ini yatu secara yuridis normatif berdasarkan bahan hukum primer, dengan menganalisa peraturan perundang-undangan yang mengatur tentang permasalahan yang dibahas, kemudian bahan hukum sekunder yang berhubungan dengan kepustaka an seperti buku, dan artikel yang memuat tentang teori, dan asas-asas hukum, kemudian penelitian lapangan yang dilakukan untuk melengkapi data-data tersebut. 


\section{Pembahasan}

\section{A. Filsafat Pancasila memandang Hak Hidup dan Hak Mati}

Dalam bagian pembukaan UUD 1945 yang terdiri dari atas empat alinea tersebut tercantum rumusan Pancasila sebagai berikut:

1. Ketuhanan Yang Maha Esa

2. Kemanusiaan yang adil dan beradab

3. Persatuan Indonesia

4. Kerakyatan yang dimpinpin oleh hikmat kebijaksanaan dalam permusyawaratan/perwakilan

5. Keadilan sosial bagi seluruh rakyat Indonesia.

Rumusan Pancasila sebagaimana tercantum dalam pembukaan UUD 1945 inilah yang secara konsitusional sah dan benar sebagai dasar negara republik Indonesia, dikatakan bahwa pokok pikiran tersebut meliputi suasana kebatinan dari UUD 1945 serta mewujudkan cita-cita hukum (rechtsidee) yang menguasai dasar hukum negara, baik yang tertulis maupun hukum tidak tertulis, dengan dinamika kenegaraan ini, batang tubuh UUD 1945 mengalami penjiwaan dari Pancasila yang terkandung dalam pokok pikiran pembukaan UUD tersebut seperti pemenuhan kemanusiaan yang adil dan beradap. Ketuhanan dalam perumusan Pancasila dan konsitusi merupakan kuatnya saham keagamaan dalam formasi kebangsaan Indonesia membuat arus besar pendiri bangsa tidak bisa membayangkan publik tanpa Tuhan. Pancasila sebagai dasar filsafat negara serta sebagai filsafat hidup bangsa Indonesia pada hakikatnya merupakan suatu nilai-nilai yang bersifat sistematis, fundamental dan menyeluruh, dapat diarikan sila-sila tersebut terpisah namun memiliki makna yang utuh dan berkaitan.

Pasal 28A UUD 1945 menyebutkan bahwa :

"Setiap orang berhak untuk hidup serta berhak mempertahankan hidup dan kehidupannya"

Kajian dalam proses hasil dari penelitian yang dilakukan di Dinas Kesehatan Angkatan Udara RSAU Dr. Moch. SALAMUN dan dokter Rahma Amalia menemukan suatu paradigma yang di bangun oleh Organisasi Profesi kedokteran bahwa tindakan euthanasia merupakan tindakan tercela dalam etika profesi, sehingga hal ini tentu baik karena tindakan yang dilakukan oleh kedokteran yang berkaitan dengan perbuatan euthanasia atau sejenis nya merupakan perbuatan melawan hukum sesuai dengan hukum pidana, yaitu pasal 344 KUHP. Perbedaan yang berkaitan dengan euthanasia antara aktif dan pasif menimbulkan hasil yang sangat berbeda dalam praktik nya. Realita dihadapkan pada etika yang sudah menjadi pedoman bagi setiap orang yang berprofesi sebagai dokter di Indonesia.

Berdasarkan argumentasi dari para praktisi diatas, penulis melihat dalam praktik nya tenaga kesehatan sebenarnya telah melakukan tindakan Euthanasia namun tidak disadari, yakni keadaan dimana seorang tenaga medis atau dokter harus memilih antara menyelamatkan pasien yang melahirkan dengan memilih menyelamatkan bayi atau ibu untuk kebaikan bersama dengan mengorbankan salah satu dari subjek hukum. Langkah yang dilakukan untuk menemukan formula pada permasalahan dan urgensi memberikan hak mati kepada seseorang, maka kita harus membedah, menguraikan isi dari pandangan filsafat Pancasila dan menterjemahkan, bagaimana seharusnya Pancasila memandang hak yang diberikan kepada setiap orang demi kebebasan dan menentukan nasib individu sehingga pemerintah 
mewujudkan kedalam hukum positif bahwa negara memberikan hak hidup sekaligus juga dengan hak mati kepada setiap masyarakat tanpa terkecuali.

Sila pertama Pancasila yakni Ketuhanan Yang Maha Esa, artinya dalam hal pembahasan ini bahwa kita dalam berbangsa dan besepakat untuk membentuk suatu negara tunduk kepada institusi yang merupakan bagian dari negara atau pemerintah. Negara meejawantahkan Ketuhanan kedalam konsep-konsep bernegara ialah kepada Hakim, hakim yang juga di istilahkan sebagai wakil Tuhan dimuka bumi ini. Sila pertama Pancasila menjadi semangat baru dan dorongan kepada masyarakat yang berkeinginan untuk melakukan Euthanasia harus mengajukannya kepada peradilan Indonesia, sehingga adanya penetapan dan juga putusan pengadilan menjadi perlindungan bagi eksekutor dalam hal ini dokter, terlepas dikabulkan atau tidak keinginan pemohon oleh seorang hakim, memang harus memenuhi kriteria dan hakim memandang hal itu penting untuk dilakukan.

Sila kedua yakni, Kemanusiaan yang adil dan beradab, artinya kondisi rakyat Indonesia dihadapkan pada kondisi fisik yang tidak sehat atau maksimal fungsi organ tubuh dari individu. Seperti yang dikatakan Gandhi yaitu, saya seorang nasionalis, tetapi kebangsaan saya adalah perikemanusiaan, 'My nationalism is humanity', alinea pertama pembukaan UUD 1945 menegaskan komitmen bangsa Indonesia pada kemanusiaan universal dengan menekankan kemutlakan hak merdeka bagi segala bangsa dan secara implisit warga nya tanpa terkecuali. Perjuangan nasional meraih kemerdekaan dan hak menentukan nasib sendiri (selfdetermination) dan idealisasi kemerdakaan bagi individu di alam kemerdekaan seperti saat ini. Indonesia memiliki pembukaan konstitusi sebagai grundnorm yang mendasarkan negara pada hukum atas dasar pengakuan akan kemerdekaan manusia, dan Indonesia telah berkomitmen pada kemanusiaan universal dalam pergaulan antrbangsa.

Sila ke empat, Kerakyatan yang dipimpin oleh hikmat kebijaksanaan dalam permusyawaratan perwakilan, memberikan keleluasaan dan kekuatan dari rakyat itu sendiri sehingga mampu mengenal dan mensepresentasikan bagaimana dinamika yang dihadapi diri nya dan negara nya. Sila kelima, Keadilan sosial bagi seluruh rakyat Indonesia. Keadilan tercipta dengan tercapainya kepastian hukum kepada setiap orang dan keadilan yang didapatkan dengan kepentingan batin masyarakat untuk menghendaki kematian.

\section{B. Penerapan Delik Euthanasia sebagaimana ketentuan dalam Pasal 344 KUHP menurut sistem Hukum Indonesia}

Hukum memaksa setiap orang untuk menjadi bagian dari hukum, dimana masyarakat harus menaati hukum atau tunduk. Teori hukum alam atau kodrat (neutral law theory ) misalnya mengatakan bahwa orang menaati hukum karena Tuhan atau alam menghendaki demikian, teori ini dianut hingga abad pertengahan dan busa dibedakan antara teori hukum alam yang bersumber kan agaman yang mengembalikan segala sesuatunya pada kehendak Tuhan.penulis memandang dengan tinjauan keberadaan Euthanasia sebagai hukum baru. ${ }^{2}$ Hukum nasional adalah hukum atau peraturan perundang-undangan yang didasarkan pada landasan ideologi dan konstitusional negara yaitu Pancasila dan UUD 1945 atau hukum yang dibangun berdasarkan kreativitas atau aktivitas yang di dasarkan atas cita rasa dan rekayasa

\footnotetext{
${ }^{2}$ Mochtar Kusumaatmadja, Pengantar Ilmu Hukum buku I, hlm. 58.
} 
bangsa sendiri. ${ }^{3}$ Sehubungan dengan itu, maka hukum nasional sebenarnya tidak lain adalah sistem hukum yang bersumber dari nilai-nilai budaya bangsa yang sudah lama ada dan berkembang sekarang. ${ }^{4}$

Pembaharuan hukum pidana harus berorientasi pada pendekatan nilai hukum nasional harus memandang euthanasia dengan melihat pada tingkat signifikan dan rasionalitas dari masyarakat, dalil dapat digunakan pada argumentasi pemerintah Indonesia yang sampai pada saat ini masih memberlakukan hukuman mati pada tindak pidana tertentu, tentu hal ini memang berbeda dengan tindakan euthanasia. Pemerintah dalam argumentasi nya mengatakan pengenaan pidana mati diperlukan untuk menghambat orang lain melakukan kerjahatan yang sama. Studi ini di berbagai negara yang kita ketahui negera-negara tersebut termasuk yang cukup memiliki perhatian untuk memerangi kejahatan sadis, telah gagal untuk membuktikan bahwa tindakan pidana mati merupakan pencegah yang lebih efektif terhadap kejahatan dibandingkan dengan bentuk-bentuk hukuman lain. Praktik bernegara yang dilaksanakan oleh negara republik Indonesia telah melarang tindakan yang disebut sebagai tindakan bunuh diri, namun satu sisi hukuman mati masih digunakan sampai pada hari ini. Apabila mendasarkan hukum pidana pada konsepsi perlindungan masyarakat/social defence, maka tugas selanjutnya adalah mengembangkanya serasional mungkin.

\section{Kesimpulan}

\section{Pancasila Memandang Hak Hidup Dan Hak Mati}

Hak hidup merupakan hak yang diberikan oleh konstitusi kita dan di ikuti dengan hukum positif untuk menjadikan hak tersebut menjadi hak yang dilindungi oleh undangundang, namun berbeda hal nya dengan hak mati, Indonesia belum memberikan landasan yang kuat dan belum menjadikan mati menjadi hak yang diberikan kepada setiap orang, seperti hal nya negara lain. Pancasila sebagai fundamental bangsa Indonesia, yang setiap sila nya memiliki semangat bangsa Indonesia ternyata memberikan ruang untuk implementasi euthanasia dilndonesia, yakni dengan diejawantahkan Ketuhanan Yang Maha Esa melalui ketetapan pengadilan sebagai mewakili Peran dan keberadaan Tuhan dalam berbangsa dan bernegara. Negara memiliki kewajiban memberikan fasilitas tersebut kepada setiap rakyatnya tanpa terkecuali, terlepas dari di gunakan atau tidak nya fasilitas tersebut.

\section{Ketentuan Hukum Terhadap Euthanasia Dalam Hukum Pidana DiIndonesia}

Euthanasia sebagai langkah mundur bagi sebagian orang, namun juga sebagai langkah cerdas memandang hukum kedepan sebagai peran nya menjadi social control bahwa hukum akan selalu bergerak mengikuti dinamika masyarakat. Ketentuan Hukum pada euthanasia diIndonesia terdapat pada Pasal 344 KUHP, menegaskan bahwa perbuatan tersebut merupakan perbuatan melawan hukum dan memiliki konsekuensi hukuman pidana. Pasal tersebut tidak tegas mengatkan sebagai pasal euthanasia, namun isi dari pasal tersebut dapat menjadi peruntukan perbuatan hukum euthanasia.

\footnotetext{
${ }^{3}$ Musa Darwin Pane, Pengganti Kerugian Negara dalam Tindak Pidana Korupsi, loGoz, Bandung, 2017, hlm. 32.

${ }^{4}$ Ibid., hlm. 32
} 


\section{SARAN}

1. Sebagai hukum yang selalu mengikuti dinamika masyarakat terlebih pada masyarakat dewasa kini, hak setiap individu akan semakin berkembang, dan tidak sesuai lagi dengan hukum ketika dibuat dalam waktu yang sudah cukup lama dan tidak konsisten dengan kepentingan-kepentingan masyarakat pada masa sekarang, hak mati harus segera diberikan melalui implementasi produk hukum.

2. Pemerintah harus segera melihat dan membahas bahkan memasukan euthanasia sebagai tindakan yang diperbolehkan dengan catatan-catatan tertentu, dengan prosesproses yang terjadi saat ini yakni dengan memasukan nya kedalam pembahasan rancangan Kitab undang-undang Hukum Pidana Nasional.

\section{Daftar Pustaka}

H sutarno. 2014. Hukum kesehatan, Euthanasia, keadilan dan hukum positif. Malang: Setara press

Kartono Muhammad. 1993. Tekhnologi Kedokteran Dan Tantangannya Terhadap Biotika. Jakarta: Gramedia Pustaka Utama

Mochtar Kusumaatmadja. 2013. Konsep-Konsep Hukum Dalam Pembangunan, Bandung: PT. Alumni, Bandung

Mochtar Kusumaatmadja. 2003. Pengantar Ilmu Hukum buku I. Bandung: Alumni

Musa Darwin Pane, 2017. Pengganti Kerugian Negara dalam Tindak Pidana Korupsi. Bandung: loGoz Publishing

Oemar sesno adji. 1985. Hukum pidana pengembangan, Jakarta: Erlangga

Otje Salman S. 2014. Teori Hukum Mengingat, Mengumpulkan dan Membuka Kembali. Bandung: Refika Aditama

Romli Atmasasmita. 2012. Teori hukum integratif. Yogyakarta: Genta Publishing

Sahat Maruli Tua Situmeang. 2017. Penahanan Tersangka. Bandung: LoGos Publishing

Satjpto Rahardjo. 2009. Hukum Progresif. Yogyakarta: Genta publishing

Teguh prasetyo. 2013. Kriminalisasi dalam hukum pidana. Bandung: Nusamedia

Yudi latif. 2011. Negara Paripurna. Jakarta: Gramedia pustaka utama

Undang-Undang Dasar Negara Republik Indonesia 1945

Kitab Undang-Undang Hukum pidana

Undang-Undang Nomor 36 Tahun 2009 Tentang Kesehatan

SRS 2014 (Balitbangkes Kemenkes Ri)

https://gagasanhukum.wordpress.com/2013/09/23/membedah-teori-hukum-integratif/ http://jusjerukkusuka.blogspot.com /2010/05/pandangan-tentang-Euthanasia.html https://news.detik.com/hasan mohonkan Penetapan Euthanasia agian ke PN jakarta pusat.

https://www.tempo.co/Ny. Agian Sudah Bisa Bicara.

www.hukum.online.com

www.negarahukum.com 